\title{
Maize in the north-eastern Mediterranean: new insights and researches
}

\author{
Luca Mocarelli \\ University of Milan Bicocca, Department of Economics, Management and Statistics
}

This volume is a first attempt at examining one of the most important and yet little studied aspects of the Colombian exchange: the introduction and diffusion of maize in some countries of Southern Europe. While the potato and its impact on European history have been examined in quite some detail, thanks to a large number of articles and monographs (McNeill 1948; Langer 1975; Salaman, 1985; Komlos 1998; McNeill 1999; Ó Gráda, Paping, Vanhaute 2007; Gentilcore 2012), the same cannot be said for maize - despite the incontrovertible importance this crop has achieved as a foodstuff in many rural areas of the Mediterranean region, as is probably most true of Italy (Alfani, Mocarelli, Strangio 2017, 46-47). But even in the case of Italy, after the seminal work of Messedaglia (1927), we can mostly find only short contributions or a few insightful syntheses (Mantelli 1998; Doria 2002; Finzi 2009; Gasparini 2015). However, much the same may be said with regard to other Mediterranean regions and countries since the historiographical 'state of the art' regarding maize is quite similar if not even more scarce (Panjek in this volume). Apart from the generally unsatisfying number of specific regional studies on maize in the earlier stages of its diffusion, one thing is certainly even more true: we lack a comprehensive vision and a comparative perspective on this process that would embrace the whole of Southern Europe.

For this reason, this volume is made up of a collection of contributions, each with a specific geographical scope. By combining regional 
historiographical reviews, case studies and researches, it gathers and offers a wider spectrum of information about maize introduction and diffusion, which enables a comparative perspective. Such an approach to investigating this topic seems extraordinarily useful, and that is the reason why we have brought together scholars from different countries who are dealing with the same issues. We decided to focus on the eastern part of the Mediterranean taking into consideration certain countries facing the Adriatic Sea. We have involved scholars from Italy, a country that, thanks to its position and size, has a central place in the Mediterranean world as well as a known historical role in maize pioneering, along with Austria, Slovenia and Serbia. The idea was to embrace the Adriatic area from the Alps to the Danube, asking these scholars to tackle the same issues in order to produce a steady basis for a truly comparative work.

The first question to be answered pertained to the chronology and geography of the diffusion of maize in the countries considered. Although it is a well-known fact that the diffusion of maize followed a west to east direction starting from Spain, a full and comparative overview of the spread of this plant is still lacking; we can mainly count on researches carried out at a narrower regional scale, also in the case of Italy (Coppola 1979, Levi 1979, Fornasin 1999, Gasparini 2002; Mocarelli, Vaquero Piñeiro 2018). The countries between the eastern Alps and the eastern Adriatic coast, addressed in this volume, represent the ideal extension of such a west-east maize diffusion route. It was our intention to check whether and when this is confirmed by historical evidence. In the case of the Balkans, it will be also fruitful to investigate the presence of another possible line of maize diffusion on a south-north axis from the Black Sea and the Ottoman Empire to Central Europe. Moreover, particular attention had to be focused on the time when maize became a widespread and familiar commodity. A good proxy for this would be the date on which maize prices began to be recorded on regulated grain markets. In Lombardy, for example, that happened in 1681 in Bergamo, in 1717 in Milan, etc. (Maffi, Mocarelli forthcoming). To both locate and map the areas where maize cultivation and consumption had become preponderant is an important issue, because there are signs of a discrepancy between the two aspects, since in many cases the areas of production and consumption did not overlap (Mocarelli 2019).

A second important issue to deal with were the reasons for a greater or lesser success of maize. An important reason, although not the only one, that explains the spread of maize, or indeed its failure to do so, would 
seem to be linked to the prevailing climate and, especially, to the amount of rainfall (Alfani 2010). On the contrary, territories where rainfall was scarce, such as most of southern Italy, seem unfavourable for maize diffusion (Venturi 1987, 237-238). Even more important for explaining the greater (or lesser) success of maize are land ownership patterns and the types of agrarian production relations and contracts. This is a really crucial issue since there is evidence that not all forms of land ownership and types of contracts favoured the introduction of maize cultivation. Thus, for example, in central Italy the predominance of a sharecropping system would appear to have made the adoption of maize more problematic than in northern Italy (Mocarelli, Vaquero Piñeiro 2018). Moreover, equally relevant in order to explain the ways in which the diffusion of maize took place seems to be the cultural dimension, that is to say the attitude of peasants with regard to this new crop (Gentilcore 2017). This will be illustrated with two different examples. It is well known that the introduction of the potato in the Italian Peninsula encountered more problems than that of maize (Gentilcore 2012, 36-63). On the other hand, a relevant role may have been played by the existing tradition in local agriculture, because the diffusion of maize seems also linked to the availability or, inversely, lack of other foodstuffs that could feed peasants easily (Lazarevic in this volume).

A third relevant issue deals with the supposed dichotomy between self-consumption and market. Usually scholars think of maize as a cereal destined above all for self-consumption, even though there is a large amount of evidence regarding the marketed sale of maize. This is a crucial point since not many studies deal with how wheat and maize interacted on the grain markets and in what way their prices might have been correlated. In particular, it would be of great interest to get a reading on the different kinds of consumer behaviour in 'normal' years as compared to years of scarcity. Were there shifts in consumption from wheat to maize and, if so, in what way did they influence prices (Mocarelli 2015, 58-63)? Another telltale regarding prices could be comparing the prices of maize with other cereals, since maize was prevalently a food for the common people; in this sense it was not so much in direct competition with wheat, but more so with rye, millet, buckwheat and the like, depending on local circumstances (comprising ecological factors, production relations and perhaps even the cooking tradition).

Self-consumption and the market both relate to the final important topic, that is nutrition and demographic impact. The impact of maize on 
peasant life is a quite well-studied issue, mainly with regard to the great diffusion of pellagra due to the exclusive consumption of polenta (De Bernardi 1984), although a proper chronology and geography of pellagra diffusion are still lacking. At the same time, it would be important to also empirically test the demographic consequences of maize diffusion and in particular the hypothesis that the widespread diffusion of maize, especially from the eighteenth century onward, was crucial in diminishing famines in Southern Europe, thus allowing a faster growth of the population than before (Alfani, Mocarelli, Strangio 2017, 46-47). By shedding more light on this aspect, it would be possible to conduct a more steady and convincing comparison between maize and its northern competitor, the potato, whose demographic consequences are interpreted in an established manner in northern European historiography (for example Nunn, Quian 2011).

The contributions of this volume give relevant insights into the aforementioned issues. If we look at the chronology of diffusion, for example, it is easy to find significant differences within countries, as the case of the Italian Peninsula clearly shows. As a matter of fact, in northern Italy maize was already known in the middle of the sixteenth century in some territories of the Venetian mainland, such as Rovigo and Este (in the Province of Padua); the famines of the 159 os accelerated its diffusion (Alfani 2011), as did the plague of 1630-1631. At the end of the seventeenth century, maize was sown throughout the Venetian mainland - from eastern Lombardy, that is the provinces of Bergamo and Brescia, to the Friuli region, in the rest of the Lombardy region, in Piedmont, and in the Papal Legations south of the Po River. During the eighteenth century it consolidated its advance both in the countryside, as demonstrated by the frequent cases of pellagra in the State of Milan (Mocarelli 2015), and in the cities, where it was becoming more and more important on the urban regulated markets, mainly in towns close to the Alpine area such as Como or Bergamo (Costantini 2016 e 2019).

On the other hand, the situation was quite different in central Italy where maize appeared later than in the northern part of the peninsula. The new crop remained a botanic curiosity for a long time and its diffusion began only at the end of the seventeenth century in Tuscany and Marche, reaching Umbria in the following century where it did not become truly important until the nineteenth century (Vaquero in this volume). In southern Italy, on the other hand, the situation was very different as the dry climate and the indisputable dominance of wheat in local agriculture left lit- 
tle room for maize diffusion, which was mostly limited to the Apennines area or to places where the geopedological characteristics and the peculiar nature of settlements greatly limited the production of wheat, as in Valdemone in Sicily. In this area in the second half of the eighteenth century, maize acted as an alternative crop grown by the population to combat production shortage and the increase in taxes on wheat and flour following the Mediterranean scarcity of 1763-64 (Fazio 2018).

Moving northeast, that is toward Carinthia, it is equally possible to note some differences as maize had the status of a botanical rarity until the early eighteenth century, even though its first appearance can be documented as early as 1559 . Moreover, its spread during the century was not homogeneous since in south-eastern Carinthia (Lower Carinthia) there was no evidence of maize cultivation until the early nineteenth century, unlike in Upper and Central Carinthia. It is important to note that the first areas where maize had spread were those north of the Alpine Divide and it is possible to suppose a maize penetration through Alpine passes linking Carinthian valleys with South Tyrol and Friuli.

If we move southeast, that is east of the Republic of Venice and the eastern Adriatic coast, i.e. to the present-day Slovenia and Croatia, the situation was even more complex. The case of the Slovenian region is exemplary in this regard since we can find many differences in the timing of the diffusion of maize and in its geographical distribution. In the middle of the seventeenth century maize was sown and consumed quite often in the south-western part, close to the Adriatic coast and Venetian Friuli, and perhaps even more so in the north-eastern part of the region (Styria), but it was almost unknown in the central area and even its wide diffusion during the eighteenth century reached the central part of the region (Carniola) only marginally; there, the population relied on maize solely in times of food crises. This was the case for a long time since in 1913 only $8 \%$ of arable land was devoted to maize in Carniola, compared to $32 \%$ and $40 \%$ in GoriziaGradisca and Istria, respectively (Lazarević in this volume).

It is also worth noting that during the eighteenth century the maize trade, centred around the harbours of Trieste and Rijeka, was becoming more and more important for import, especially (but not only) during the food crises, and for export. While the imports signal that the consumption surpassed local production capacities, the exports of maize through both sea ports seem to be linked to another very interesting trait that has emerged in our case studies. In fact, in the Slovenian region it is possible to 
point out two different main axes of maize diffusion. The first line of diffusion followed the west-east axis (the Po Plain, Venice, Friuli, Trieste and Rijeka). The second one, which might explain the early diffusion and importance of maize during the seventeenth century in eastern Slovenia (and Austrian Styria), as well as the exports in the eighteenth century, is the diffusion of maize in and from the Balkans, following the Danube and its tributary rivers from the south-east to the north-west. In Slovenia we see these two axes converge.

It is evident that, in order to explain these different timings and grades of maize diffusion, it is necessary to reflect on the reasons for its greater or lesser success. In the cases considered in this volume, climate seems to matter but is less important than the agricultural conditions, i.e. landownership and contracts, cultural habits and the presence of alternative plants.

With regard to climate, it will suffice to note that the areas where maize encountered its first success were characterized by favourable climatic conditions, namely warm and sufficiently moist summer months. At the same time, maize cultivation was common in the lowlands and flatlands and wherever it was possible to rely on streams. However, from the eighteenth century onward, the introduction of varieties which could be successfully cultivated in colder areas and the extraordinary yield ratios of maize favoured a widespread diffusion to such an extent that during the nineteenth century wherever the soil and the climate allowed maize cultivation the peasants would plant it. Afterwards the diffusion was unstoppable until it reached the point that in Carinthia maize for silage and grain was grown on 24,943 hectares or $62.5 \%$ of the arable land (Drobesch in this volume). The same can be said for some areas of Slovenia and, even more so, of Serbia where $46 \%$ of arable land was already devoted to maize in 1867 (Lazarević in this volume).

However, during the first phases of maize diffusion in the early modern period, climate was a necessary precondition but not the only one. The local agricultural conditions could be even more important. I refer mostly to landownership and tenure conditions, that is to say the "relations of production". Where peasants did not own the land, which was mostly the case in the areas where agriculture was more productive, the landowner's choices regarding what to sow were determinant. In Bergamasco, for example, at the beginning of the seventeenth century the Consorzio della Misericordia Maggiore, the main landowner of the province, opposed maize introduction since it did not want to run the risk of reducing the amount of land 
devoted to wheat (Moioli 1983, 630-631). The same happened in the areas shaped by the predominance of sharecropping, such as central Italy, where the introduction of maize was similarly slowed down. In fact, within the economy of the sharecropping podere, despite the splitting of the yield between the landowner and peasants, the former was in a stronger position and was mainly interested in wheat, wine and oil production (Mineccia 1983).

In northern Italy the diffusion of maize increased after the plague of 1630-1631, owing to the growing contractual power of peasants who survived the epidemic and the awareness of landowners that maize, due to its high productivity and the fact that its growth did not overlap with that of wheat, could become pivotal for peasants' alimentation without compromising wheat production. Moreover, being more productive than the other crops eaten by peasants such as millet or buckwheat (notwithstanding it required hard work) and being suitable for sowing together with other crops, such as vines or pumpkins, it soon found favour with both the landowners and the peasants.

Thus, starting with the eighteenth century, wherever the soil and weather conditions and the agricultural framework allowed it, maize diffusion was becoming unstoppable. In the case of the possessions of Bonate di sopra, Comun Nuovo e Nova owned by the Consorzio della Misericordia Maggiore in the plain of Bergamasco where the production of maize, which had still been marginal in the decade 1650-1660, overtook that of wheat in the decade 1711-1720, mostly thanks to the pressure and requests of peasants (Moioli 1983, 688-707).

In some territories, however, the features of local agriculture left no room for a remarkable diffusion of maize. That is the case in most of southern Italy where, on the one hand, wheat cultivation for export predominated, as in the case of Sicily, and where, on the other hand, the centrality of transhumant breeding, as in Tavoliere of Apulia, limited grain cultivation (Russo 2016). On this plain about 110,00o hectares of land were used by the Dogana, the institution that regulated sheep transhumance, eight months a year, after which time the land was given to the landowners for their own use during the summer (Mercurio 1990, 12). At the end of the warmest season, in fact, millions of sheep left Abruzzo and the mountains of Molise and headed for the Apulian Plain, as did the flocks of central Italy, but they headed for the Tuscan Maremma, where Dogana dei Paschi operated, and to the Pontine Marshes south of Rome (Ciuffetti 2019, 220-225). 
The case of the large area east of Italy is different since the current state of historiography only allows for hypothesizing. First of all, in the present-day Carinthia, Slovenia, Croatia and Serbia, a late feudal or manorial system prevailed for centuries, as it had in a large portion of southern Italy, although it differed significantly here since the peasant population lived on their farms in small villages. In this part of Europe, landlords and peasants alike had been conditioned by the fact that the tributes were defined a priori in official registers, meaning that the landlord had to receive and the peasant had to cultivate precise amounts of certain grains. This limited the possibility of agricultural modernization, as Sandgruber noted decades ago (1982, 260-263).

On the other hand, it is well known that in Slovenian lands, for example, landlords tended to change the nature of tributes from in kind to money since the fifteenth century and through the early modern period, although it was not a linear process (Panjek 2011). In these cases, peasants could more freely choose which kind of crop to cultivate or what else to produce and then sell it to get the money needed to pay tributes. In such a situation, maize cultivation could become a strategic choice since it was suitable for self-consumption but also had a growing market - on the other hand, it is documented how peasants in the present-day western Slovenia would sell their produce and use the revenue to buy maize on the market for their own consumption (Panjek in this volume).

The issue of taxation is really an interesting one to deal with in order to understand peasants' choices. In some parts of Sicily, for instance, peasants started to cultivate maize precisely because, being a new crop, it was free of taxes. However, its increasing cultivation was soon noticed by the authorities and, consequently, a tithe was imposed on maize, making peasants abandon its cultivation (Fazio 2018). Something similar happened in Slovenia with buckwheat from the sixteenth century onwards. In short, unlike on the Italian Peninsula, where we may lean on numerous studies, the relation between landownership and tenancy conditions on the one hand and maize diffusion on the other is still an open research question in the eastern Alpine and Adriatic regions.

The decision to sow maize, however, did not depend only on the institutional framework or on economical evaluations, but also on cultural habits. As a matter of fact, the introduction of a new crop required an open mind and an interest in innovations since it was necessary in many cases to abandon the well-known plants and ways of cultivation. One of the rea- 
sons for the late diffusion of potatoes in Italy was the peasants' indifference toward a crop that grew under the soil and was consequently considered dangerous and even capable of transmitting leprosy. After all, in 1765 the Encyclopédie defined the potato thus: "elle ne sauroit être comptée parmi les alimens agréables... On reproche avec raison à la pomme de terre d'être venteuse; mais qu'est-ce que des vents pour les organes vigoureux des paysans \& des manoeuvres?" (Encyclopédie 1765, ad vocem).

The same could be said of maize since at the beginning peasants had to make do with a crop suitable for both animal and human nutrition; later on, some doubts arose mostly in the areas where peasants were used to other crops. Thus, for a certain period the consumption of maize among the rural population was hindered due to mistrust (Levi 1979), although there is evidence that in northern Italy maize substituted the traditional food of the peasants during the crises of the second half of the sixteenth century (Cazzola 1991). In other territories, as Zarko Lazarevic clearly shows in this volume, the local population could be very strongly attached to traditional crops. That was the case in some parts of Slovenia, where buckwheat dominated for centuries, slowing the advance of maize.

Despite these important differences among territories, maize cultivation has increased impressively in the countries considered in this volume, especially from the eighteenth century onward. This huge increase in production requires tackling an important, usually underestimated, issue, namely that of maize as a marketable crop that is not used only for self-consumption. It is necessary to overcome the simplistic idea that "a dualistic cereal growing... took place: the wheat one, market-oriented; the maize one, the key element of subsistence and a poor economy" (Doria 2002, 572). In fact, in many territories, starting with the eighteenth century, it is easy to find a dual grain market based on wheat on the one hand and on maize on the other.

In northern Italy, wheat and white bread dominated only in the main cities such as Milan, where the consumption of wheat accounted for more than $80 \%$ of total consumption. In Como, a much smaller town close to the mountains, the consumption of wheat in normal years was just below $50 \%$ of total consumption. Maize made up the difference, particularly in bad harvest years. In fact, on the Como market wheat amounted to between $45 \%$ and $48 \%$ of cereals sold during the good harvest years, while in the bad years, wheat only amounted to between $35 \%$ and $37 \%$ of the total (these data were taken from the State Archive registers in Como, Archivio storico civ- 
ico, cc. 396-411 and refer to the period 1808-1834). Finally, in mountainous and rural communities, it is normal to find places where $80-90 \%$ of cereal consumption was represented by maize.

Thus, it seems very interesting to examine this dual grain market, taking into account different variables and, in particular, the population distribution, i.e. the presence or absence of a significant urban network, and the population density. The case of northern Italy shows a peculiar situation since we can find some big cities, many towns and "quasi-towns" close together, and a high and widespread population density, even in the large Alpine area. That is particularly true of Lombardy as the following table clearly shows.

Table I. Mountain area in Lombardy, inhabitants and population density (1790)

\begin{tabular}{lcccc}
\multicolumn{1}{c}{ Territories } & Surface $\left(\mathrm{km}^{2}\right)$ & $\%$ of mountain area & Population & Density $\left(\mathrm{in} . / \mathrm{km}^{2}\right)$ \\
\hline Bresciano and Riviera & 4,882 & 55 & 340,000 & 70 \\
\hline Bergamasco & 2,490 & 82 & 220,000 & 88 \\
\hline Cremasco & 572 & 0 & 41,000 & 71 \\
\hline State of Milan & 7,892 & 23 & $1,117,000$ & 141 \\
\hline Lombardy & 15,836 & 42 & $1,718,000$ & 108
\end{tabular}

Sources: for Eastern Lombardy Mocarelli 1996,342-343 and Mocarelli 1997, 267-268; for the State of Milan Romani 1950, 25, 43

Let me focus on two issues that emerge from this situation: on the one hand, the grain market outside the cities and the kind of grain sold on it, and the price trend on the other. Usually, historians dealing with prices and markets in the early modern period refer almost exclusively to the big cities and to the annone, ignoring the fact that most of the population lived outside the cities. Even in one of the most urbanized areas of Europe in that period, such as northern Italy, urbanization rates varied between 20 $30 \%$, meaning that around $70-80 \%$ of the population lived in rural areas. Therefore, rural markets, where maize was gaining a growing importance, played a relevant role in the supply of the rural population since the countryside was not characterized only by self-consumption.

These markets were important especially for the supply of areas with a high demand for grain (villages with thousands of inhabitants or those engaged in manufacture) or with low grain production (e.g. mountain areas). The case of the Italian Alpine area, which met both conditions, is exemplary since it suffered, as did the biggest European cities, a structural lack of 
food; in its case it was due to the small plots of arable land that were usually barren. It is precisely the poorness of agriculture in the hilly and mountainous areas and the necessity for their inhabitants to work in manufacturing activities in order to get the money to buy grain that is at the core of Mendels' model (Mendels 1972), recently reinterpreted in a convincing way by Aleksander Panjek (2017).

Therefore, same as Milan or Paris, the Alpine areas had to buy grain elsewhere but, unlike the big cities of the plain, they could not count on the production of their surrounding areas, because the environmental situation was unfavourable. As a result, they had to pay exceptionally high grain prices due to the transport costs. On the southern rim of the Alps were located several small towns with grain markets where every year thousands of tons of grain were produced and sold at high prices. That was the case, for example, of the grain market in Desenzano that supplied the villages of the riviera of Lake Garda and southern Trentino inhabited by around 45,000-60,00o people, equalling the size of a big city (Bertoni 2014).

In spite of the availability of grain transportation along an important waterway, i.e. Lake Garda, the costs of reaching Desenzano and the pressure of a substantial demand made prices on the market very high, mostly in the years of bad harvests. In 1782, for example, wheat was sold at 81.8 lire per hectolitre, while in a big city like Milan the price was only 59.7 lire. It is interesting to note that the prices in Desenzano were perfectly aligned with those of markets close to the Alpine area, where there was a structural lack of grain, such as Bergamo and Udine, where the prices in 1782 were 80.8 and 81.2 lire per hectolitre, respectively (these data are from the forthcoming database built by Giulio Ongaro and myself on grain prices in Italy during the eighteenth century).

It is true, however, that in these rural markets, maize was becoming increasingly important. If we consider the sessions of the Desenzano market in August, when the availability of wheat was at its peak, and in December, when the same applied to maize, we can find these data for the period between 1751 and 1791: in August 1751, 306 some of wheat and 621 of maize were sold; in August 1791, 608 and 1,384, respectively; in December 1751, 159 some of wheat and 332 of maize; in December 1791, 568 and 1,434, respectively. If millet is also considered, it is easy to note that on the Desenzano market wheat accounted only for $20-30 \%$ of the grain sold. Even more interesting is the fact that on such markets close to the hills and mountains the centrality of maize during the eighteenth century was reflected in the prices; in some 
years, it is possible to observe an unusual phenomenon, namely that maize prices overtook those of wheat. That happened especially during food crises, e.g. in May 1764, July-August 1773, July 1794 (Zalin 1990, 351). On the contrary, in markets located in areas with great producers of grain the difference between wheat and maize prices was huge, often more than double, as it is possible to note in the case of Mantua (Vivanti 1967, 423).

Prices and their trend are the second important issue to deal with considering markets. As Manuel Vaquero clearly shows in this volume, many questions are still open. If and how wheat and maize prices interacted; if there are any co-movements; if the prices show a possible integration of markets or not; who the buyers were; the kind of relation existing between production and market (in the case of Umbria, it seems that the sale of maize on markets preceded its widespread cultivation). I can add two other issues. The first is the relation between the level of prices and the availability of grain. In the case of Desenzano, there is, in fact, evidence of high prices in spite of a good availability of grain. In 1780, for example, 71,000 some of wheat were sold at prices between 36 and 38 lire per soma, while in 1790 , when 86,000 some were sold, the price exceeded 70 lire (Zalin 1990, 345, 349-351). The same happened in Cuneo where in 1765 93,00o emine of wheat were sold at an average price of 2.16 lire, and in 1776 only $12,450 \mathrm{em}$ ine at 2.14 lire. Therefore, it is possible to think that the prices depended not only on the quantity of supply, as is usually believed, but in some cases also on the level of demand. Such is the case of Cuneo, where in 1765 an extraordinary demand from the army was recorded (Bonelli 1968, 824-828).

The second issue is the role played by maize on the market. According to Coppola, the growing production of maize in the State of Milan, starting in the eighteenth century, resulted in a lower price of wheat, to the point that maize determined the general price of grain in Milano (Coppola 1979, 104). But if it is true that people bought maize when wheat prices rose, then there is the problem of determining at which price level this shift occurred. Moreover: what happened when wheat and maize prices were similar? Did consumers shift toward wheat or not?

In my opinion, the only certainty is that the advent of maize not only offered peasants the opportunity to escape hunger but also made the grain market wider and more complex. This evidence calls for a radical re-thinking of the debate about the standard of living and the "great" or "little" divergence that dominated economic history over the last two decades. In fact, we have a bulk of studies in which real wages, the living condi- 
tions and divergence are calculated taking into account only the urban prices of wheat, mainly in the big cities, ignoring other towns, rural markets and maize. The flaw of such an approach seems very evident (Hatcher, Stephenson 2018) and has produced unconvincing general statements as to the little divergence between Northern and Southern Europe (Mocarelli, Ongaro 2019, 131-140).

The last important issue to deal with is the demographic consequences of maize diffusion and, in particular, the hypothesis that its widespread diffusion was crucial in diminishing famines in Southern Europe. In consequence, starting in the eighteenth century, there was room for the population to grow faster than before (Alfani, Mocarelli, Strangio 2017, 46-47). However, in some territories, this change happened even earlier. As Alessio Fornasin clearly shows in this volume, the spread of maize in an area of Friuli during the seventeenth century directly affected population growth. This connection "seems to work in Malthusian terms: the introduction of maize stimulated population growth and not vice versa". This path of research seems very interesting but not yet well practised. More studies in this direction will allow us to abandon a negative view of the consequences of maize diffusion, focused only on the spread of pellagra, and to make fruitful comparisons with the growth of potato consumption in Northern Europe. It is an important issue because, if maize in Southern Europe played the same role as potatoes in northern countries, we find nothing comparable to the Irish potato famine in southern countries.

In conclusion, I think that the contributions in this volume show the importance of dealing with maize diffusion, its modalities and consequences, and offer us some stimulating new insights into this issue. The awareness that we need more studies on Mediterranean countries, such as France, Spain, the Balkans, in order to get a more comprehensive view of the history of this pivotal crop is surely a good start.

\section{Literature}

Alfani, G. 2010. 'Climate, population and famine in Northern Italy: general tendencies and Malthusian crisis, ca. 1450-180o'. Annales de Démogra phie Historique 120: 23-53

Alfani, G. 2011. 'The Famine of the 1590s in Northern Italy. An Analysis of the Greatest "System Shock” of Sixteenth Century'. Histoire \& mesure, 16-1: $17-50$ 
Alfani, G., Strangio, D., Mocarelli, L. 2017. 'Italy'. In Famine in European history, edited by G. Alfani, C. Ó Gráda, 25-46. Cambridge: Cambridge Universty Press

Bertoni, R. 2014. 'Il mercato a Desenzano in epoca veneta', in Atti del Convegno Il mercato a Desenzano in epoca veneta e l'odierna agricoltura, 17-54. Bedizzole: Bontempi, 2014

Bonelli, F. 1968. 'Mercato dei cereali e sviluppo agrario nella seconda metà del Settecento: un sondaggio per il cuneese' Rivista Storica Italiana, 80-3: 785-829

Cazzola F. 1991. 'L'introduzione del mais in Italia e la sua utilizzazione alimentare (sec. XVI-XVIII).' Pact, 26 (8): 109-127

Ciuffetti, A. 2019. Appennino. Economie, culture e spazi sociali dal medioevo all'età contemporanea. Roma: Carocci editore

Coppola, G. 1979. Il mais nell'economia agricola lombarda. Dal secolo XVII all'unità. Bologna: Il Mulino

Costantini, F. 2016. "In tutto differente dalle altre città". Mercato e contrabbando dei grani a Bergamo in epoca veneta. Bergamo: Centro studi e ricerche archivio bergamasco

Costantini, F. 2019. 'Commercio e contrabbando di cereali in area lombarda tra Seicento e Settecento'. In Le vie del cibo. Italia settentrionale (secc. $X V I-X X)$, edited by M. Cavallera, S. Conca, B.A. Raviola, 175-189. Roma: Carocci

De Bernardi, A. 1984. Il mal della rosa. Denutrizione e pellagra nelle campagne italiane tra '8oo e '9oo. Milano: Franco Angeli

Doria, M. 2002. 'Le colture del nuovo mondo'. In Storia dell'agricoltura italiana, II, Il medioevo e l'età moderna, edited by G. Pinto, C. Poni, U. Tucci, 569-578. Firenze: Edizioni Polistampa

Encyclopédie 1765. Encyclopédie ou dictionnaire raisonné des sciences, des arts et des métiers. Neufchastel: Chez Samuel Faulche \& Compagnie

Fazio, I. 2018. Maize in eastern Sicily (1766-1786). A case study following the great Mediterranean scarcity of 1763-64. Paper presented at the World Economic History Congress. Boston July 29-August 3

Finzi, R. 2009. "Sazia assai ma da poco fiato". Il mais nell'economia e nella vita rurale italiane. Secoli XVI-XX. Bologna: CLUEB

Fornasin, A. 1999. 'Diffusione del mais e alimentazione nelle campagne friulane del Seicento'. In Vivere in Friuli. Saggi di demografia storica, edited by M. Breschi, 21-42. Udine: Forum 
Gasparini, D. 2002. Polenta e formenton. Il mais nelle campagne venete tra XVI e XX secolo. Sommacampagna: Cierre

Gasparini, D. (ed.). 2015. Il mais nella storia agricola italiana iniziando dal Polesine. Rovigo: Minelliana

Gentilcore, D. 2012. Italy and the Potato: A History, 1550-20oo. London: Continuum Publishing Corporation

Gentilcore, D. 2017. 'The Impact of New World Plants, 1500-1800: The Americas in Italy.' In The New World in Early Modern Italy 1492-1750, edited by E. Horodowich, 190-205. Cambridge: Cambridge University Press

Hatcher, J.- Stephenson J. 2018. Seven Centuries of Unreal Wages. The Unreliable Data, Sources and Methods that have been used for Measuring Standards of Living in the Past, edited by J. Hatcher, J. Stephenson. London: Palgrave

Komlos, J. 1998. 'The New World's Contribution to Food Consumption During the Industrial Revolution'. Journal of European Economic History 27, 1: $67-82$

Langer, W.L. 1975. 'American Foods and Europe's Population Growth 17501850'. Journal of Social History 8,2: 51-66

Levi, G. 1979. 'Innovazione tecnica e resistenza contadina: il mais nel Piemonte del ‘6oo’. Quaderni Storici 42: 1092-1100

Maffi, L, Mocarelli, L. forthcoming. 'Supplying Milan. The complex dynamics of annona and ancient regime markets Complexity and efficiency: Milan in the $17^{\text {th }}$ and $18^{\text {th }}$ centuries'. In Italian victualling systems in the early modern age, $16^{\text {th }}$ to $18^{\text {th }}$ century, edited by L. Clerici. London: Palgrave Mcmillan

Mantelli, R. 1998. 'L'epoca della diffusione del mais. La maiscoltura nell'evoluzione economica dell'Italia (fine XVI secolo - fine XIX secolo)'. In Prodotti e tecniche d'oltremare nelle economie europee. Secc. XIII-XVIII, edited by S. Cavaciocchi, 451-465. Firenze: Le Monnier

McNeill, W.H. 1948. 'The Introduction of the Potato into Ireland'. Journal of Modern History 21, 3: 218-21

McNeill, W.H. 1999. 'How the Potato Changed the World's History'. Social Research 66, 1: 67-83

Mercurio, F. 1990. La frontiera del Tavoliere. Agricoltura, bonifiche e società nel processo di modernizzazione del Mezzogiorno tra '8oo e '9oo. Foggia: Amministrazione provinciale di Capitanata

Messedaglia, L. 1927. Il mais e la vita rurale italiana. Saggio di storia agraria. Piacenza: Federazione Italiana dei Consorzi Agrari 
Mendels, F. 1972. 'Proto-Industrialization: the first phase of the industrialization process'. Journal of Economic History 32, 1: 241-61

Mineccia, F. 1983. 'Note sulle fattorie granducali del pisano occidentale nell'età moderna: Antignano, Casabianca, Collesalvetti, Nugola, S. Regolo e Vecchiano.' In Agricoltura e aziende agrarie nell'Italia centro-settentrionale (secoli XVI-XIX), edited by G. Coppola, 285-341. Milano: Franco Angeli.

Mocarelli, L. 1996. 'Una realtà in via di ridefinizione: l'economia bresciana tra metà Settecento e Restaurazione', in Brescia e il suo territorio, 335-351. Milano: Cariplo

Mocarelli, L. 1997. 'L'economia bergamasca tra conferme e nuovi sviluppi', in Bergamo e il suo territorio, 258-282. Milano: Cariplo

Mocarelli, L. 2015. 'Ripensare le crisi alimentari: lo Stato di Milano nel secondo Settecento', in "Moia la carestia” La scarsità alimentare in età preindustriale, edited by M. Vaquero Piñeiro, M.L. Ferrari, 39-63. Bologna: Il Mulino

Mocarelli, L. 2019. 'Gebirgsregionen ernähren: Getreidemärkte und Getreidehandel in der Lombardei des 18. Jahrhunderts', in Relire l'altitude. La terre et ses usages. Suisse et espaces avoisinants, XIIe-XXIe siècles, edited by L. Lorenzetti, Y. Decorzant, A. Head-Konig, 149-169. Neuchatel: Éditions Alphil-Presses universitaires suisses

Mocarelli, L., Vaquero Piñeiro, M. 2018. 'El maíz en Italia, siglos XVI-XIX: precios, mercados y haciendas agrícolas (dos casos de estudio: Lombardía y Umbría)'. Obradorio de Historia Moderna 27: 21-48

Mocarelli, L., Ongaro G. 2019. Work in Early Modern Italy, 1500-180o. London: Palgrave

Moioli, A. 1983. 'Una grande azienda del Bergamasco durante: i secoli XVII e XVIII', in Agricoltura e aziende agrarie nell'Italia centro-settentrionale (secoli XVI-XIX), edited by G. Coppola, 599-724. Milano: Franco Angeli

Nunn, N., Qian, N. 2011. 'The potato's contribution to population and urbanization: evidence from a historical experiment'. Quarterly Journal of Economics 126: 593-650

Ó Gráda, C., Paping, R., Vanhaute, E. (eds.) 2007. When the Potato Failed: Causes and Effects of the Late European Subsistence Crisis, 1845-1850. Turnhout: Brepols

Panjek, A. 2011. "Not demesne but money: lord and peasant economies in early modern Western Slovenia." Agricultural History Review 59, II, 293-311. 
Panjek, A. 2017. 'The Integrated Peasant Economy as a Concept in Progress', in Integrated Peasant Economy in a Comparative Perspective, edited by A. Panjek, J. Larsson, L. Mocarelli, 11-49. Primorska: University of Primorska Press

Romani, M. 1950. Un secolo di vita economica lombarda 1748-1848. Milano: Vita e Pensiero

Russo, S. 2016. 'Il conflitto tra agricoltura e pastorizia transumante nella Dogana di Foggia in età moderna'. Mélanges de l'Ecole française de Rome. Antiquité 128: 341-347

Salaman, R. 1985. The history and social influence of the potato. Cambridge, New York: Cambridge University Press

Sandgruber, R. 1978. 'Die Agrarrevolution in Österreich. Ertragssteigerung und Kommerzialisierung der landwirtschaftlichen Produktion im 18. Und 19. Jahrhundert', in Österreich-Ungarn als Agrarstaat. Wirtschaftliches Wachstum und Agrarverhältnisse in Österreich im 19. Jahrhundert, edited by A. Hoffman, 195-271. Wien, ?

Venturi, F. 1987. Settecento riformatore, V, L'Italia dei lumi (1764-179o), 1, La rivoluzione di Corsica. Le grandi carestie degli anni sessanta. La Lombardia delle riforme. Torino: Einaudi

Vivanti, C. 1967. 'I prezzi di alcuni prodotti agricoli a Mantova nella seconda metà del XVIII secolo', in I prezzi in Europa dal XIII secolo a oggi, edited by R. Romano, 409-425. Torino: Einaudi

Zalin, G. 1990. Terre e uomini nel Mediterraneo e in Europa. Ricerche di storia dell'agricoltura dall'antichità alla rivoluzione agraria. Verona: Libreria Universitaria Editrice 